\title{
Article \\ Motif Kerjasama antara KRG (Kurdish Regional Government) Irak
dengan Pemerintah Turki (2013-2016)
}

Maryam Jamilah ${ }^{1}$

${ }^{1}$ Ilmu Hubungan Internasional, Universitas Andalas, Sumatera Barat, Indonesia

\begin{tabular}{l} 
SUBMISSION TRACK \\
\hline : 5 February, 2018 \\
Final Revision :11 March, 2018 \\
Available Online: 30 May 2018 \\
KEYWORD
\end{tabular}

Motives, Cooperation, KRG, Turkey,

Neorelism, Interest

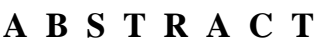

This research aims to analyze motives behind cooperation between KRG (Kurdish Regional Government) and Turkey government by using neorealism perspective of International relations. On neorealism, state as rational actor will try to maintain their existance or to survive in international system of anarchy. Significhant change of KRG and Turkey government relation, which was in bad term bercause of Turkey rejection of KRG as political entity but then they cooperate after AKP (adalet ve Kalkinma Partisi) or Justice and Development Party won the Turkey election in 2002. That is the main focus of this research, the purpose is to formulize motives behind coopertion between those two entities.The findings of this research is there are two main motives of cooperation between them: first, good relation between them is in order to achieve their own self interest, second, mutual benefit that they get from cooperation is more bigger.
\end{abstract}

\section{A B S T R A K}

\section{KATA KUNCI}

Motif, Kerjasama, KRG, Turki, Neorealism, Kepentingan

\section{CORRESPONDENCE}

Phone:085263494319

E-mail: maryamjamilahmj73@gmail.com
Penelitian ini bertujuan untuk menganalisis motif dibalik kerjasama antara KRG (Kurdish Regional Government) dan pemerintah Turki dengan menggunakan perspektif neorealism. Dalam perspektif neorealism, negara merupakan aktor rasional yang berusaha menjaga eksistensinya dan bertahan di sistem internasional yang anarki. Perubahan signifikan hubungan KRG dengan Turki, yang pada mulanya buruk ditandai dengan penolakan Turki terhadap identitas KRG sebagai identitas politik namun kemudian KRG memiliki hubungan kerjasama dengan Turki pasca AKP memenangkan pemilu di Turki tahun 2002. Perubahan hubungan tersebut menjadi fokus utama dalam penelitian ini. Tujuannya adalah untuk mengetahui motif dibalik kerjasama tersebut. Penelitian ini menemukan bahwa ada dua motif utama: hubungan baik antara dan Turki bertujuan untuk mencapai self interest mereka masing-masing, kedua, mutual benefit yang mereka dapatkan jauh lebih besar ketika kerjasama terjalin.

\section{Pendahuluan}

Pada tanggal 16 November 2013, terjadi peristiwa penting bagi warga $\mathrm{KRG}$ dan Turki, dimana pemimpin dari kedua negara yaitu Perdana Menteri Recep Tayip Erdogan dan Presiden KRG Masoud Barzani bertemu di kota Kurdi Diyarbakir. Momen ini menarik perhatian media nasional di Turki, disamping itu pidato yang disampaikan oleh Presiden Barzani diterjemahkan ke dalam bahasa Turki, salah satu pernyataan beliau yang menyorot perhatian adalah: "Long live Turk-Kurd brotherhood, long live freedom, and long live peace"." Hal tersebut mengindikasikan

\footnotetext{
${ }^{1}$ UmutUras, Kurdish Leader Makes Historic Turkey Visit, www.aljazeera.com 20 November 2013, tanggalakses: 2 Desember 2016, pukul: 10.22
} 
terjadinya perubahan signifikan terkait hubungan antara KRG denganTurki, dimana dulunya kedua pihak ini bukanlah duaentitas yang berhubungan baik satu sama lain.

Semenjak tahun 1990 an, Irak merupakan partner dagang utama dari Negara Turki. Sebagai balasan atas aliran produk-produk Turki ke Irak, Turki menerima minyak dari pipa-pipa yang dipasang dari wilayah utara Irak. Signifikansi Irak bagi perekonomian Turki ini menjadikan stabilitas politik dan keamanan di Irak juga menjadi kepentingan nasional dari Negara Turki yang berbatasan langsung dengan Irak. $^{2}$ Hal ini yang kemudian mendasari penolakan Turki terhadap pembentukan negara Kurdi yang merdeka di Irak atau KRG. Pada tahun 2006 dan 2007 Turki mengancam untuk membatasi hubungan ekonomi dan perdagangan antara Turki dan Irak, jika pemerintah pusat Irak tidak melakukan tindakan nyata terhadap PKK (Partai Buruh Kurdi) di area perbatasan. Kemudian Turki juga melakukan langkahlebih lanjut dengan cara merencanakan implementasi embargo makanan dan energi terhadap Irak sebagai respon terhadap insiden di perbatasan yang menewaskan 40 orang warga Turki di perbatasan. $^{3}$

Data diatas menunjukkan bahwa pemerintah Turki tidak mengakui KRG sebagai entitas bangsa Kurdi dan lebih mengedepankan hubungan bilateral dengan pemerintah pusat Irak di Baghdad. Namun, posisi Turki tersebut kemudian berubah secara drastis pasca penarikan angkatan militer Amerika Serikat pada tahun 2012 dari wilayah Irak. AKP yang menjadi partai pemenang pemilu pada tahun 2011 kemudian meningkatkan kerjasama dengan KRG dengan mengundang Presiden KRG Masoud Barazani dan PM KRG Nechirvan

\footnotetext{
${ }^{2}$ HasanTurunc, Turkey and Iraq, Turkey's Global Strategy Special Report 7, 2011, hal: 40 ${ }^{3}$ Ibid, hal: 43
}

Barzani ke Ankara pada bulan Mei 2012. Kunjungan ini kemudian menghasilkan kontrak yang berisi mengenai transfer minyak dari KRG ke Turki (kesepakatan ini tanpa adanya pertimbangan dan otoritas dari pemerintah pusat Irak). ${ }^{4}$

Permasalahan utama yang menarik untuk diteliti dalam tulisan ini adalah motif dibalik perubahan hubungan antara KRG dengan Turki serta bagaimana hubungan kerjasama tersebut terjalin sejak tahun tahun 2013 pasca berakhirnya invasi Amerika Serikat terhadap Irak hingga tahun 2016 saat kedua pemimpin entitas ini melakukan pertemuan.

Untuk mencapai tujuan dari penelitian ini metode penelitian yang akan peneliti gunakan adalah metode penelitian kualitatif, dengan pendekatan deskriptif analisis, dimana tujuan dari penelitian kualitatif deskriptif adalah untuk menghasilkan sebuah kesimpulan yang komprehensif mengenai kejadian spesifik yang dialami oleh individu maupun suatu kelompok. ${ }^{5}$

Salah satu penelitian sebelumnya yang membahas hubungan antara Turki dengan KRG yaitu Turkey Foreign Policy and the Kurdistan Regional Government yang ditulis oleh Marianna CHAROUNTAKI. Artikel tersebut menjelaskan tahapan-tahapan hubungan antara Ankara dengan Erbil yang telah terbentuk sejak Perang Teluk tahun 1991. Dalam tulisan ini disebutkan bahwa yang menjadi salah satu faktor yang mempengaruhi kebijakan luar negeri Turki terhadap KRG adalah kepentingan strategis Turki untuk mewujudkan neo-ottomanism dengan menjaga perdamaian dan

${ }^{4}$ Gallia Lindenstrauss\&FurkanAksoy,

Turkey and Northern Iraq: Tightening Relations in Volatile Environment, Strategic Assessment Vol.15, No 3 Oktober 2012, hal: 53

${ }^{5}$ Vickie A. Lambert, Clinton E. Lambert, Qualitative Descriptive Research : An Acceptable Design, hal : 2 
kesejahteraan negara-negara tetangganya dengan menggunakan soft power. ${ }^{6}$

Penelitian lainnya yaitu

Desecuritiztion of Turkish Foreign Policy Toward Northern Iraq: Actor, Context, and Audience, karya Ozlem Kayhan Pusane. Dalam tulisannya, Pusane menjelaskan bahwa adanya perubahan arah kebijakan Turki dari securitization menjadi desecuritization menyangkut hubungan dengan KRG. Hal ini dikaitkan dengan perubahan domestik di Negara Turki, dimana pasca kudeta militer Turki pada tahun 2016, terjadi perubahan signifikan terkait hubungan antara oknum militer dengan sipil di Turki yang kemudian juga mempengaruhi arah kebijakan luar negeri dari pemerintah Turki termasuk kebijakan terhadap KRG. ${ }^{7}$

Kedua penelitian diatas membahas isu hubungan antara Turki dengan KRG dengan melihat dari sudut pandang pemerintah Turki. Sedangkan dalam tulisan ini peneliti melihat pemulihan hubungan antara Turki dengan KRG dari sudut pandang kedua belah pihak, hal apa yang melatar belakangi kerjasama terjalin antara Turki dan KRG berdasarkan pandangan masing-masing.

\section{Metode Penelitian}

Dalam penelitian ini peneliti menggunakan metode analisa data kualitatif yang dikembangkan oleh Miles dan Huberman yang terdiri dari tiga tahap : ${ }^{8}$

a) Reduksi data (data reduction)

\footnotetext{
${ }^{6}$ Marianna CHAROUNTAKI, Turkish

Foreign Policy and the Kurdistan Regional

Government, PERCEPTIONS, Winter 2012,

Volume XVII, No 4, hal 185-208

${ }^{7}$ Ozlem Kayhan Pusane, Desecuritization of Turkish Foreign Policy Towards Northern Iraq: Actor, Context and Audience, ECPR 2017 General Conference, Isik University, Istanbul: 2017, hal:1-33

${ }^{8}$ Matthew B.Miles, A.Michael Huberman, Qualitatve Data Analysis, Sage Publications : 1994, hal : 18
}

Yang terdiri dari proses organisasi data dan ketegorisasi data dengan konsep dimana data akan disusun secara sistematis.

b) Penyajian data (data display)

Proses menghubungkan data dengan kerangka konseptual yang digunakan

c) Penarikan kesimpulan dan verifikasi (conclusion drawing and verification)

Penelitian ini menggunakan teori kerjasama internasional dalam perspektif neorealism, sebagaimana dijelaskan oleh Robert Keohane dalam tulisannya yang berjudul After Hegemony, beliau berasumsi bahwa karakteristik politik internasional bersifat anarki.Sistem yang anarki tersebut menjadikan lingkungan internasional dengan aktor-aktor negara yang egois, anomik dan setiap kerjasama internasional yang dilakukan oleh negara dalam sistem tersebut hanya bertujuan untuk mewujudkan self-interest masingmasing aktor. ${ }^{9}$

Kenneth A.Oye dalam tulisannya yang berjudul "Explaining Cooperation under Anarchy: Hypotheses and Strategies", dijelaskan bahwa penyebab terjadinya kerjasama antar aktor internasional yang rasional dalam keadaan politik anarki adalah karena mutual benefit yang didapatkan jauh lebih besar dibanding dengan mutual defection. ${ }^{10}$ Dengan kata lain melalui kalkulasi untung rugi, maka negara akanmelakukan kerjasama dengan pihak lain hanya jika keuntungan yang diperoleh jauh lebih besar dibanding kemungkinan kerugian yang akan terjadi.

Dari dua pendapat pemikir diatas dapat disintesis menjadi kerangka

\footnotetext{
${ }^{9}$ Robert Keohane, After Hegemony, chs 5,
} 6 esp, hal: 73

${ }^{10}$ Kenneth A. Oye, Explaining Cooperation under Anarchy: Hypotheses and Strategies, Cambridge University Press, World Politics, Vol 38 No 1, Oktober 1985, hal: 4 
konseptual mengenai kerjasama internasional dalam perspektif neorealisme, yaitu ada dua hal yang menyebabkan terjadinya kerjasama antar aktor-aktor politik internasional:

1. Kerjasama tersebut bisa mewujudkan self-interest masing-masing pihak

2. Keuntungan bersama atau mutual benefit yang diperoleh dari hubungan kerjasama lebih besar dibanding kerugian.

Jika kedua indikator tersebut tidak ada dalam hubungan kerjasama antar negara, maka hubungan kerjasama tidak akan bisa dilaksanakan dalam lingkungan internasional yang anarki dan penuh konflik.

\section{Pembahasan}

\section{A. Sejarah Hubungan Kerjasama antara KRG-Turki \\ Kurdish Regional Government}

(KRG) sudah menjadi permasalahan utama menyangkut bangsa Kurdi di Timur Tengah semenjak akhir dari Perang Dunia kedua, terutama setelah dua perang Irak yang terjadi pada tahun 1991 dan tahun 2003. Setelah peristiwa tersebut bangsa Kurdi di Irak secara perlahan tapi pasti mendapatkan status sebagai negara quasi-independent (yang tidak sepenuhnya merdeka). Secara internasional KRG telah diakui sebagai entitas federal Irak dengan Presiden Barzani sebagai kepala negara. ${ }^{11}$

Sejarah pembentukan KRG merupakan hasil dari penarikan diri tentara Irak di bagian utara dengan diberlakukannya no fly zone yang mencegah angkatan udara Irak beroperasi di area Irak Utara.Pemberlakukan zona larangan terbang tersebut merupakan hasil dari rencana kemanusiaan kolektif untuk menjaga populasi bangsa Kurdi Irak yang

${ }^{11}$ Henry J. Barkey, On the KRG, the Turkish-Kurdish Peace Process and the Future of the Kurds, Woodrow Wilson Center, 2015, hal: 3 diprakarsai oleh Amerika, Inggris, Perancis dan Turki. ${ }^{12}$

Dukungan Presiden Turki Turgut Ozal terhadap terbentuknya "safe heaven" bagi bangsa Kurdi Irak pada bulan April 1991 merupakan langkah awal hubungan antara Turki dan bangsa Kurdi Irak, hal ini ditandai dengan penyebaran 100.000 pasukan Turki di sepanjang perbatasan antara Turki dan Irak dan persetujuan Ozal bagi AS untuk menyerang Saddam Husein dari basis udara Turki pada tanggal 18 Januari $1991 .{ }^{13}$ Disamping itu Turki juga menutup aliran pipa minyak di Kirkuk Yumurtalik yang menghubungan aliran ekspor minyak Irak dan Turki pada tahun 1990, serta embargo perdagangan Turki dengan Irak. Namun hal penting dalam kebijakan-kebijakan Turki tersebut adalah kecendrungan Turki untuk melihat KRG bukan sebagai sebuah entitas namun hanya sekumpulan orang dari bangsa Kurdi yang tinggal di Irak. ${ }^{14}$

Fokus utama pemerintah Turki pada perang teluk 1991 pada hakikatnya adalah untuk menghentikan jumlah pengungsi dari Irak Utara memasuki wilayah Turki, disamping itu juga untuk mencegah terbentuknya entitas Kurdi yang merdeka. Hal ini dilakukan oleh pemerintah Turki dengan tujuan mengamankan area pegunungan di perbatasan dari para teroris. ${ }^{15}$ Adapun langkah bantuan yang dilakukan oleh Ozal terhadap bangsa Kurdi Irak diatas dilakukan oleh pemerintah Turki

${ }^{12}$ Marriana Charountaki, Turkish Foreign Policy and the Kurdistan Regional Government, PERCEPTIONS, Winter 2012 Volume XVII,

Number 4, hal: 186

${ }^{13}$ Stephen F. Larrabee, Turkey Rediscovers the Middle East, Foreign Affairs, Vo.86, No. 4 (JuliAgust 2007), hal: 104

${ }^{14}$ Marianna Charountaki, The Kurds and US Foreign Policy, Routledge Studies in Middle eastern Politics, hal: 175

${ }^{15}$ Gallia Lindenstrauss, Turkey and Northern Iraq: Tightening Relations in a Volatile Environment, Strategic Assesment, Vol 15, No. 3 Oktober 2012, hal: 50 
sebagai strategi untuk mencari solusi terkait masalah bangsa Kurdi yang ada dalam internal Turki. Pada saat itu Ozal bahkan menyediakan paspor diplomatik Turki terhadap pimpinan KRG Barzani dan Jalal Talabani, yang mana tindakan dari Ozal ini berhasil menciptakan kesepakatan damai dengan pemimpin PKK (Partai Buruh Kurdi) di Turki Abdullah Ocalan pada tahun 1993. ${ }^{16}$ Namun pasca kematian dari Presiden Ozal, pemerintah Turki kemudian memilih pendekatan yang militaristik dalam menanggapi permasalahan Kurdi.Selama periode ini Perdana Menteri Tansu Ciller dilancarkan operasi unit spesial yang berdampak pada pengingkaran identitas etnik bangsa Kurdi dan semakin memperumit konflik, terbukti dengan terjadinya beberapa pembunuhan. ${ }^{17}$

Pada tahun 2007 pasca kemenangan

partai AKP (Partai Keadilan dan Pembangunan) di Turki, pemerintah mengeluarkan kebijakan Kurdish Opening yang menjamin adanya hak individu dan kolektif bagi bangsa Kurdi. Pada rezim AKP ini dimulai kembali negosiasi dengan PKK dan peningkatan dialog dengan KRG di Irak. ${ }^{18}$ Membaiknya hubungan pemerintah Turki dengan bangsa Kurdi di Irak juga berdampak terhadap dinamika hubungan antara KRG dengan Turki.

$$
\text { Hubungan KRG-Turki yang }
$$

semakin membaik pasca pemerintahan AKP terbukti dengan disepakatinya beberapa kerjasama sejak tahun 2008 terkait dalam beberapa bidang termasuk perdagangan, energi dan keamanan. Dari total hasil perdagangan Turki-Irak sebesar

${ }^{16}$ Gareth Jenkins, Turkey and Northern Iraq: An Overview, Jametown Foundation, 2008, hal: 13

${ }^{17}$ Ronald D. Crelinsten, Terrorism and Counter Terrorism in a Multi-Centric World: Challenges and Opportunities, Terrorism and Political Violence 11, no 4, 1999, hal: 172

${ }^{18}$ Gallia Lindenstrauss, Turkey and Northern Iraq: Tightening Relations in a Volatile Environment, Strategic Assesment, Vol 15, No. 3 Oktober 2012, hal: 50
\$11.95 milyar, sekitar \$7 milyar merupakan hasil dari perdagangan antara Turki-KRG. ${ }^{19}$ Perbedaan jumlah total perdagangan tersebut mengindikasikan hubungan kerjasama perdagangan yang dilakukan Turki dengan KRG bernilai lebih besar ketimbang kerjasama perdagangan Turki dengan Irak sendiri. Ditambah lagi pada tahun 2012, Turki dan KRG melakukan kesepakatan untuk membangun sebuah pipa gas dan dua pipa minyak yang menghubungkan secara langsung Irak Utara (KRG) dengan Turki. ${ }^{20}$ Kesepakatan pembangunan pipa ini secara tidak langsung memberikan otoritas perekonomian yang besar bagi pemerintah KRG, karena dengan kesepakatan ini proses aliran minyak dan gas dari KRG ke Turki bisa dikirimkan langsung tanpa perlu persetujuan dari pemerintah pusat Irak di Baghdad.

Selain kerjasama dalam bidang ekonomi, kedua pihak ini juga mengadakan kerjasama di bidang keamanan terutama menyangkut isu terorisme.Pada tanggal 17 November 2016, Perdana Menteri KRG Barzani mengadakan pertemuan dengan PM Turki Yildirim di Ankara yang membahas mengenai hubungan kerjasama dalam mengatasi tindakan terorisme dari kelompok teroris manapun, baik itu kelompok Daesh ${ }^{21}$ dan PKK. ${ }^{22}$ Dalam

\footnotetext{
${ }^{19}$ Middle East Research Institute, Forum 2015 Session 6: Turkey-KRG Relations: Sharing Visions for the future, http://www.meri-korg/multimedia/forum-2015-session-6-turkey-krgrelations-sharing-visions-for-the-future/ , tanggal akses: 08 Desember 2016, pukul: 13:11

${ }^{20}$ Middle East Research Institute, Forum 2015 Session 6: Turkey-KRG Relations: Sharing Visions for the future, http://www.meri-korg/multimedia/forum-2015-session-6-turkey-krgrelations-sharing-visions-for-the-future/ , tanggal akses: 08 Desember 2016, pukul: 13:11

${ }^{21}$ Daesh adalah akronim dari al- Dawla alislamiyah al-Iraq al-Sham (Islamic State of Iraq and the Levant)

${ }^{22}$ Merve Aydogan, Turkey, KRG Restate Cooperation Against Terror, Daily Sabah War on Terror, http://www.dailysabah.com/war-on-
} 
pertemuan tersebut, pembahasan lainnya adalah menyangkut kemungkinan didirikannya kantor perwakilan KRG di Ankara pada tahun 2017 untuk memperkuat hubungan bilateral antara dua entitas. ${ }^{23}$

\section{B. Self-interest dalam hubungan kerjasama KRG-Turki \\ - Kepentingan KRG}

1. Pengakuan sebagai negara yang merdeka (recognition of independence)

Bagi pemerintah KRG, Irak adalah negara yang tidak demokratis dan memiliki karakteristik sektarian yang kuat serta unkonstitusional.Pandangan pemerintah KRG tersebut memicu KRG untuk mempertimbangkan kembali komitmen bangsa Kurdi dalam hal integritas wilayah dengan Iraq serta struktur sebagai negara federasi Irak. ${ }^{24}$ Selama bertahun-tahun Presiden KRG Barzani berusaha untuk menyampaikan aspirasi untuk terwujudnya Negara Merdeka Kurdi. ${ }^{25}$ Pada tahun 2005 diadakan referendum secara informal di KRG yang hasilnya menunjukkan lebih dari 95\% vote mendukung terbentuknya negara merdeka bagi bangsa Kurdi di Irak. ${ }^{26}$ Pengakuan sebagai sebuah entitas

terror/2016/11/24/turkey-krg-restate-cooperationagaints-terror-1479933512, tanggal akses: 8

Desember 2016, pukul: 13:46

${ }^{23}$ Merve Aydogan, Turkey, KRG Restate Cooperation Against Terror, Daily Sabah War on Terror, http://www.dailysabah.com/war-onterror/2016/11/24/turkey-krg-restate-cooperationagaints-terror-1479933512, tanggal akses: 8 Desember 2016, pukul: 13:46

${ }^{24}$ " On the eve of Kurdish New Year,

President Barzani delivers key address"

http://www.krg.org/articles/detail.asp?lngnr=12\&sm $\mathrm{ap}=02010100 \& \mathrm{rnr}=223 \& \mathrm{anr}=43432$, tanggal akses: 16 Desember 2016, pukul: 08:07

${ }^{25}$ Ofra Bengie, Will Barzani declare

independence?, Jerusalem Post,

http://www.jpost.com/Opinion/Op-

EdContributors/Article.aspx?id=267115 , tanggal

akses: 16 Desember 2016, pukul: 08:31

${ }^{26}$ Bill Park, Turkey, US and the KRG:

Moving Parts and Geopolitical Realities, Insight

Turkey Vol.14/No.3/2012, hal: 110 negara yang merdeka dan mampu untuk self-determination merupakan kepentingan nasional yang sangat vital bagi bangsa Kurdi di Iraq pada saat ini.

Referendum yang dilakukan oleh KRG tersebut menimbulkan respon yang negatif dari pemerintahan Irak di Baghdad.Tindakan dari Presiden Barzani diambil tidak lama setelah kunjungan beliau ke Ankara Turki pada bulan April 2005. ${ }^{27}$ Sehingga disinyalir bahwa hubungan yang erat dengan Turki memberikan angin segar bagi terciptanya negara merdeka bagi bangsa Kurdi di Irak. Sambutan pemerintah Turki terhadap pimpinan KRG melalui pemberian karpet merah sebagaimana layaknya penyambutan seorang kepala negara meningkatkan semangat KRG untuk mewujudkan kemerdekaan bagi negaranya.

\section{Mandiri secara ekonomi dari pemerintahan Irak (economic independence)}

Adapun kepentingan nasional dari KRG lainnnya menyangkut kerjasama dengan pemerintah Turki ini adalah kepentingan untuk terlepas dari ketergantungan secara ekonomi dengan pemerintah Irak di Baghdad.Keadaan ekonomi KRG pada saat ini jauh lebih stabil dibanding dengan wilayah Irak lainnya yang masih berada dalam taraf kemiskinan.Namun yang menjadi permasalahan utama dalam ekonomi KRG adalah tingkat ketergantungan yang sangat tinggi terhadap pendapatan minyak yang didistribusikan oleh pemerintah Irak. Aliran dana per bulan yang dikirim oleh Irak sangat penting bagi perekonomian KRG, sebelum dananya sampai ke KRG

${ }^{27}$ Bill park, Turkey, the US and the KRG:

Moving Parts and the Geopolitical Realities, Insight Turkey Vol 14, No 3, 2012, hal: 110 
masyarakatnya belum mendapatkan upah kerja. $^{28}$

Jika aliran dana dari Baghdad mengalami penundanaan atau tersendat, maka pemerintah KRG mengalami kekurangan kas untuk membayar pejabat negara dan begitu juga dengan anggaran militer. Permasalahan ini telah terjadi berkali-kali dalam kurun waktu dua tahun belakangan. Meskipun area Irak utara yang merupakan territorial KRG yang kaya akan sumber minyak dan gas, pemerintah $\mathrm{KRG}$ dan Irak telah berkomitmen untuk membagi pendapatan dari minyak dan gas tersebut dengan formula distribusi $83 \%$ untuk Baghad dan $17 \%$ untuk pemerintah KRG. ${ }^{29}$ Pembagian tersebut didominasi oleh pemerintah pusat Irak di Baghdad.

Melalui bantuan mediator Turki, distribusi pendapatan minyak $17 \%$ untuk KRG tersebut bisa langsung dialirkan ke pemerintah KRG tanpa harus melalui pemerintah pusat Irak di Baghdad. Ditambah lagi, dengan perkembangan rute ekspor minyak dan gas melalui Turki, kerentanan ekonomi KRG terhadap penundanaan dan situasi ekonomi di Baghdad menjadi semakin berkurang.Pengelolaan pendapatan ekspor minyak secara mandiri oleh KRG merupakan sebuah langkah maju dalam meningkatkan kemerdekaan dan pengakuan secara de facto terhadap negara KRG serta juga mengurangi pengaruh dan tekanan dari pemerintah Irak terhadap KRG. ${ }^{30}$

\footnotetext{
${ }^{28}$ David Pullock, The Future of the Iraqi Kurds, The Washington Institute for Near East Policy, hal: 7

${ }^{29}$ David Pullock, The Future of the Iraqi Kurds, The Washington Institute for Near East Policy, hal: 8

${ }^{30}$ Till F. Paasche \& Howri Mansurbeg, Kurdistan Regional Government-Turkish energy relations: a complex partnership, Eurasian Geography and Economics, 2014, diakses dari http://www.tandfonline.com/page/terms-andconditions, hal: 4
}

\section{Mengatasi ketakutan terhadap pengaruh Iran (containing Iran influence)}

Iran merupakan salah satu negara tetangga yang ditakuti oleh bangsa Kurdi.Berdasarkan laporan dari pemerintah KRG, keberadaan negara Iran merupakan ancaman bagi KRG.Hal ini berdasarkan pada dua pertimbangan, pertama Iran memiliki aset-aset inteligen dalam teritorial KRG dan punya kapabilitas untuk menyebarkan pengaruh kelompok inteligen tersebut, pertimbangan kedua yaitu pemerintah Iran mendukung kelompok teroris Islamis Kurdi. ${ }^{31}$ Pada umumnya masyarakat KRG merasa bahwa area Irak utara yang mereka tempati tidak sedang menghadapi ancaman dari kelompok Islam radikal, namun daerah Irak lainnya potensi kemunculan kelompok-kelompok teroris masih sangat besar.Bangsa Kurdi Irak merasakan ketakutan tersendiri jika mereka berpaling atau tidak mematuhi Iran, karena potensi ancaman kelompok teroris yang bisa dikirim oleh Iran ke area KRG kapan saja. $^{32}$

Meskipun begitu, PUK $^{33}$ tetap menjaga hubungan ekonomi yang kuat dengan Iran, salah satu bentuk hubungan ekonomi dengan Iran adalah di daerah perbatasan The Haj Umran pemerintah Iran memenuhi kebutuhan listrik masyarakat di ibukota PUK Sulaymania. Hal ini menjadi penting bagi masyarakat PUK karena faktanya sumber listrik merupakan salah satu komoditas yang langka bagi warga $\mathrm{KRG}$, umumnya masyarakat hanya bisa

\footnotetext{
${ }^{31}$ David Pollock, The Kurdish Regional Government in Iraq: An Inside Iraq, The Washington Institute for Near East Policy, hal:16

${ }^{32}$ David Pollock, The Kurdish Regional Government in Iraq: An Inside Iraq, The Washington Institute for Near East Policy, hal:16

${ }^{33}$ PUK (Partai Union of Kurdistan) adalah salah satu partai pemeritahan terbesar di KRG
} 
memperoleh maksimal satu jam energi listrik tiap 24 jam atau tiap harinya. ${ }^{34}$

Hubungan kerjasama dan aliansi yang dibentuk dengan pemerintah Turki diharapkan mampu untuk mengurangi ketergantungan pemerintah KRG terhadap bantuan dari Iran.Disamping itu, juga diharapkan untuk meminimalisir ancaman keamanan bagi KRG yang disebabkan oleh kelompok Islam radikal yang dikuasai oleh pemerintah Iran.

\section{- Kepentingan Turki}

\section{Membendung Permasalahan Bangsa Kurdi di dalam Negeri (containing Turkey internal problem of Kurdish)}

Salah satu kepentingan nasional dari Turki terkait hubungan kerjasama dengan KRG adalah untuk membendung permasalahan bangsa Kurdi dalam negeri.Isu bangsa Kurdi merupakan salah satu tantangan terbesar dalam pemerintahan Turki sendiri.Pemerintah Turki menyadari bahwa peningkatan relasi yang baik dengan KRG bisa membuktikan bahwa pemerintahan Turki dibawah AKP mampu menjalin hubungan yang baik dengan bangsa Kurdi.Strategi ini dilakukan dengan tujuan untuk mengurangi tegangan dengan PKK (Partai Buruh Kurdi) dan berusaha untuk menemukan jalan kompromi dengan bangsa Kurdi Turki tersebut.

Berikut adalah penuturan dari penasehat kebijakan luar negeri Perdana Menteri Turki yang bernama Ibrahim Kalin, "the current state of (domestic) Kurdish issue alone cripples Turkey's ambitions to speak with confidence about democracy, transparency and human rights in Middle East". ${ }^{35}$ Permasalahan bangsa Kurdi di

\footnotetext{
${ }^{34}$ Soner Cagapte, Turkey's Changing Relations with Iraq Kurdistan Up Baghdad Down, Policy Focus 122, Oktober 2012, hal: 9

${ }^{35}$ Ibrahim Kalin, Turkey and the Middle East: Ideology or Geo-politics?, in Private View, No 13 (Autumn 2008), http://www.setav.org/en/turkeyand-the-middle-east-ideology
}

Turki telah menjadi duri dalam daging bagi pemerintah Turki.Ambisi Turki untuk menjadi negara hegemon di kawasan Timur Tengah dan menjadi agen demokratisasi di kawasan terhalang oleh adanya konflik internal dengan bangsa Kurdi. Dari penyataan diatas dapat dilihat adanya indikasi bahwa pemerintah Turki memiliki kepentingan yang besar untuk menjaga hubungan baik dengan KRG, karena melalui relasi KRG-Turki maka tegangan dan tuntutan dari PKK di Turki bisa dibendung oleh pemerintah Turki.

Keberadaan partai buruh Kurdi atau Kurdistan Worker Party di Turki telah berkembang ke dalam aktivitas-aktivitas yang tergolong dalam tindakan terorisme, dengan lebih dari 700 orang dilaporkan menjadi korban dari tindakan yang dilakukan oleh PKK dalam kurun waktu empat belas bulan terakhir. ${ }^{36}$ Dalam pandangan pemerintah Turki, Presiden Suriah Basar Al-Assad dan negara Iran merupakan dua aktor yang mendukung aksi terorisme yang dilakukan oleh PKK tersebut. $^{37}$

Deputi Perdana Menteri Turki Bulent Arinc menuntut Iran atas tuduhan mendukung tindakan bom PKK di Gaziantep pada bulan Agustus 2012. ${ }^{38}$ Dinamika ini kemudian

\footnotetext{
${ }^{36}$ Turkish Ministry of Foreign Affairs,
} Statement Made by Ismail Cem, Foreign Minister on the Special Security Meeting Held between Turkey and Syria 20 Oktober 1998 (Unofficial

Translation) http://www.mfa.gov.tr/_p_statementmade-by-ismail-cem -foreign-minister_on-thespecial-security-meeting-held-between-turkey-andsyria br_october-20_-1998 br unofficialtranslation p.en.mfa, tanggal akses: 17 Desember 2016, pukul: 08:21

${ }^{37}$ Iranian Spy Scandal Sparks Outrage in Turkey, Journal of Turkish Weekly, 12 September 2012 ,

http://www.ekurd.net/mismas/articles/misc2012/6/st ate6311.htm tanggal akses 20 Desember 2016, pukul: 20.56

${ }^{38}$ Turkey Probes Possible Iran Link in Bombing Near Syria, Haaretz, 23 Agustus 2012, http://www.haaretz.com/news/middle-east/turkey- 
menstimulus pemerintah Turki untuk melakukan pendekatan dengan KRG di Irbil. Turki berharap melalui hubungan kerjasama dengan KRG, maka Turki bisa mengajak Turki untuk bekerjasama dalam melawan PKK di pegunungan Qandil, yang berbatasan dengan wilayah Irak Utara yang dikuasai oleh KRG. ${ }^{39}$

\section{Mengimbangi kekuatan dan pengaruh Iran di wilayah Timur Tengah terutama di Irak (Balancing power of Iran)}

Salah satu perubahan besar dalam arah politik luar negeri Turki adalah mengaplikasikan kebijakan luar negeri dengan mengedepankan diplomasi yang bersahabat. Kebijakan tersebut disebut dengan "zero poblems with neighbors", dalam kebijakan ini terdapat lima prinsip utama, yaitu: keseimbangan antara kebebasan dengan kemananan, tidak ada permasalahan dengan negara-negara tetangga, kebijakan yang multidimensi serta multi-track, diskursus diplomasi berdasarkan fleksibilitas. ${ }^{40}$

Jika Turki berhasil mencegah jatuhnya Irak terutama KRG kedalam pengaruh dan kekuasaan Iran, hal ini akan membuktikan peran penting Turki sebagai salah satu aliansi Amerika Serikat dan anggota NATO. Lebih jauh lagi peran konstruktif Turki di Irak juga mendapatkan pengakuan dari Uni Eropa dan mempengaruhi laporan kemajuan keanggotaan Turki. ${ }^{41}$

probes-possible-iran-link-in-bombing-near-syria1.460372, tanggal akses: 20 Desember 2016, pukul: 21.53

${ }^{39}$ Soner Cagaptay \& Tyler Evans, Turkey’s Changing Relations with Iraq, Policy Focus 122, Oktober 2012, hal: 1

${ }^{40}$ Ahmet Sozen, A Paradigm Shift in

Turkish Foreign Policy: Transition and Challenge, Turkish Studies (Routledge) XI, no.1 (Maret 2010), hal: 103-123

${ }^{41}$ Mesut Ozcan, From Distance to Engagement: Turkish Policy toward the Middle

\section{Mutual benefit dalam hubungan kerjasama KRG-Turki \\ - Keuntungan KRG}

Berikut adalah pernyataan dari Perdana Menteri KRG Nechirvan Barzani, "our relationship with Turkey has reached strategic level, and it is mutually beneficial". ${ }^{42}$ Adapun salah satu keuntungan yang didapatkan KRG melalui hubungan kerjasama dengan pemerintah Turki adalah pada saat ini KRG menguasai setengah dari total perdangangan Turki dengan Irak dan Turki merupakan partner dagang kedua terbesar bagi KRG setelah Jerman.Sekitar puluhan ribu masyarakat Turki bekerja dan telah membangun bisnis di area KRG dan banyak diantara mereka adalah warga negara Turki yang berkebangsaan Kurdi. ${ }^{43}$

KRG telah menandatangani hampir 50 kontrak perjanjian pembagian produksi dengan beberapa perusahaan-perusahaan Turki. Salah satu sektor yang paling menjanjikan di area KRG adalah perdagangan minyak, namun permasalahan yang dihadapi KRG adalah pemerintah masih belum bisa mengekspor minyak ke negara lain. Pipa minyak yang menghubungkan aliran minyak dari Kirkuk ke Turki dikuasai oleh pemerintah pusat Irak di Baghdad, sehingga KRG tidak bisa dengan bebas menjual kekayaan sumber minyaknya ke negara lain. ${ }^{44}$ Pada bulan Mei 2012, Ankara dan Irbil mengumumkan niat kedua entitas untuk membangun pipa

East, Iraq and Iraqi Kurds, Insight Turkey 13, no 2, 2011, hal: 82

${ }^{42}$ Gonul Tol, Forum 2015 Session 6: Turkey-KRG Relations: Sharing Visions for the future, Middle East Research Institute,http://www.meri-k-org/multimedia/forum2015-session-6-turkey-krg-relations-sharing-visionsfor-the-future/ , 2013 tanggal akses: 08 Desember 2016, pukul: 13:11

${ }^{43}$ Henri J. Barkey, Iraq and the Kurd: the High stakes hydrocarbons gambit, United States Institute of Peace: Special Report, No 237, Mei 2010

${ }^{44}$ Bill Park, ibid, hal: 121 
minyak dan gas dari KRG menuju Turki. ${ }^{45}$ Dengan dibangunnya pipa ini maka pemerintah KRG dengan bebas mengekspor minyaknya ke negara Turki tanpa harus melalui persetujuan dari Irak.

\section{- Keuntungan Turki}

AKP telah memprioritaskan perkembangan ekonomi Turki dan pertumbuhan angka ekspor, dan peningkatan standar hidup masyarakat sebagai hal utama dalam pemerintahan.Kekayaan sumber daya minyak yang dimiliki oleh KRG (Kurdish Regional Government) merepresentasikan pasar ekspor yang besar, potensi ini tidak bisa diabaikan begitu saja oleh pemerintah Turki. ${ }^{46}$ Sehingga kerjasama ekonomi dengan KRG memiliki nilai yang besar bagi perekonomian Turki.

$\begin{array}{ccc}\text { Turki } & \text { juga } & \text { mendominasi } \\ \text { perekonomian } & \text { di wilayah KRG, }\end{array}$
diperkirakan $80 \%$ komoditas yang dijual di KRG adalah barang yang diimpor dari Turki.55\% dari perusahaan-perusahaan asing yang terdaftar di KRG juga merupakan perusahaan-perusahaan Turki. ${ }^{47}$ Perusahaan-perusahaan privat Turki tersebut telah melakukan investasi dalam jumlah yang besar di wilayah KRG, terutama di area yang kaya sumber minyak seperti Tak Tak, Khar Mor dan Chemchemal. $^{48}$

Bukan saja keuntungan di bidang ekonomi, hubungan kerjasama dengan KRG di bidang energi ini juga berkaitan dengan ambisi geopolitik negara Turki yang

\footnotetext{
${ }^{45}$ Shwan Zulal, The real deal behind

Turkish-Kurdish oil Plans: pipe dreams or reality?, 22 Juni 2012

http://www.ekurd.net/mismas/articles/misc2012/6/st ate6311.htm , tanggal akses: 20 Desember 2016, pukul: 20.27

${ }^{46}$ Henri J. Barkey, On the KRG, the Turkish-Kurdish Peace Process, and the Future of the Kurds, Global Turkey in Europe, 2015, hal: 3

${ }^{47}$ Hasan Turunc, Turkey and Iraq,Turkey's Global Strategy Special Report 7, 2011, hal: 44

${ }^{48}$ ibid
}

menuntut dibutuhkannya sumber energi dalam jumlah besar. ${ }^{49}$ Berdasarkan letak geografis dari Turki yang berada di antara kawasan Eropa yang merupakan pasar energi terbesar di dunia dan kawasan Timur Tengah yang adalah supplier energi terbesar di dunia, Turki memiliki ambisi untuk menjadikan negaranya sebagai daerah sentral energi yang penting bagi kedua kawasan. ${ }^{50}$

\section{Kesimpulan}

Berdasarkan deskripsi dan penjabaran menyangkut sejarah hubungan antara KRG dan Turki serta analisis dengan menggunakan perspektif neorealisme, adapun motif dibalik terjalinnya hubungan antara dua entitas ini adalah:

\section{KRG}

Self Interest Recognition of independence

Economic independence Containing Iran influence

Mutual benefit

$$
\text { Economic benefit Economic benefit }
$$

\section{Economic benefit}

Containing Turkey internal problem of Kurdish

Balancing power of Iran
Kepentingan nasional KRG yang melandasi terjalinnya kerjasama dengan Turki ada tiga yaitu: pengakuan sebagai negara yang merdeka, kepentingan akan kemerdekaan ekonomi dan yang terakhir kepentingan untuk membendung pengaruh Iran di Irak. Sedangkan bagi pemerintah Turki adapun kepentingan nasional yang menjadi pertimbangan hubungan kerjasama tersebut adalah: mengatasi permasalahan bangsa Kurdi di dalam negeri dan untuk

${ }^{49}$ Galip Altinay, Short-run and Long-run Elasticties of Import Demand for Crude Oil in Turkey, Energy Policy 35, 2007, hal: 58

${ }^{50}$ Till F. Paasche \& Howri Mansurbeg, Kurdistan Regional Government-Turkish energy relations: a complex partnership, Eurasian Geography and Economics, Routledge, 2014, hal: 1 
Maryam Jamilah | Motif Kerjasama Antara KRG (Kurdish Regional Government) Irak Dengan Pemerintah Turki (2013-2016)

mengimbangi kekuatan Iran sebagai hegemoni di Timur Tengah.

Sebagaimana yang telah dijabarkan melalui data-data sebelumnya bahwa kedua pihak mendapatkan keuntungan secara ekonomi melalui kerjasama tersebut, keuntungan dalam sektor perdagangan dan juga sektor energi. Kerjasama ekspor minyak antara
KRG dan Turki menguntungkan KRG dalam hal kebebasan dalam mengekspor sumber daya minyak di area Irak Utara, sedangkan bagi pemerintah Turki kerjasama energi tersebut membantu mewujudkan ambisi Turki untuk menjadi daerah sentral energi baik untuk Asia maupun untu Eropa. 
Maryam Jamilah | Motif Kerjasama Antara KRG (Kurdish Regional Government) Irak Dengan Pemerintah Turki (2013-2016)

\section{DAFTAR PUSTAKA}

"On the eve of Kurdish New Year, President Barzani delivers key address" http://www.krg.org/articles/detail.asp?!ngnr=12\&smap=02010100\&rnr=223\&anr=43432 , (tanggal akses: 16 Desember 2016)

Altinay, Galip. Short-run and Long-run Elasticizes of Import Demand for Crude Oil in Turkey, Energy Policy 35, (2007)

Aydogan,Merve,Turkey, KRG Restate Cooperation Against Terror, Daily Sabah War on Terror, http://www.dailysabah.com/war-on-terror/2016/11/24/turkey-krg-restate-cooperationagaints-terror-1479933512, (tanggal akses: 8 Desember 2016)

B.Miles, A.Michael Huberman, Qualitative Data Analysis, Sage Publications (1994)

Bengie, Ofra,Will Barzani declare independence?,Jerusalem Post, http://www.jpost.com/Opinion/Op-EdContributors/Article.aspx?id=267115 ， (tanggal akses: 16 Desember 2016)

Cagapte,Soner, Turkey's Changing Relations with Iraq Kurdistan Up Baghdad Down, Policy Focus 122, (Oktober 2012), 1

Charountaki, Marianna, The Kurds and US Foreign Policy, Routledge Studies in Middle Eastern Politics (2012), 175

Charountaki, Marriana, Turkish Foreign Policy and the Kurdistan Regional Government, PERCEPTIONS, Volume XVII, Number 4, (Winter2012), 185-208

Descriptive Research, http://www.mu.ac.in/myweb test/Research\%20Methadology-Paper3/Chapter-5.pdf, (tanggal akses : 16 November 2014)

Henri J. Barkey, Iraq and the Kurd: the High stakes hydrocarbons gambit, United States Institute of Peace: Special Report, No 237, (Mei 2010)

Henry J. Barkey, On the KRG, the Turkish-Kurdish Peace Process and the Future of the Kurds, Woodrow Wilson Center, (2015)

Iranian Spy Scandal Sparks Outrage in Turkey, Journal of Turkish Weekly, 12 September 2012, http://www.ekurd.net/mismas/articles/misc2012/6/state6311.htm (tanggal akses 20 Desember 2016)

Jenkins,Gareth. Turkey and Northern Iraq: An Overview, Jametown Foundation, (2008)

Kalin,Ibrahim. Turkey and the Middle East: Ideology or Geo-politics?,in Private View, No 13

(Autumn 2008), http://www.setav.org/en/turkey-and-the-middle-east-ideology Kenneth A. Oye.

Explaining Cooperation under Anarchy: Hypotheses and

Strategies, Cambridge University Press, World Politics, Vol 38 No 1, (Oktober, 1985), 4

Keohane, Robert, After Hegemony, chs 5, 6 esp

Lindenstrauss, Gallia, Turkey and Northern Iraq: Tightening Relations in a Volatile Environment, Strategic Assesment, Vol 15, No. 3 (Oktober 2012), 50

Middle East Research Institute, Forum 2015 Session 6: Turkey-KRG Relations: Sharing Visions for the future, http://www.meri-k-org/multimedia/forum-2015-session-6-turkey-krgrelations-sharing-visions-for-the-future/, (tanggal akses: 08 Desember 2016)

Ozcan, Mesut. From Distance to Engagement: Turkish Policy toward the Middle East, Iraq and Iraqi Kurds, Insight Turkey 13, no 2, (2011), 82

Park, Bill,Turkey,US and the KRG: Moving Parts and Geopolitical Realities, Insight Turkey Vol.14/No.3/(2012)

Pullock,David, The Future of the Iraqi Kurds, The Washington Institute for Near East Policy, (2000)

Pollock, David, The Kurdish Regional Government in Iraq: An Inside Iraq, The Washington Institute for Near East Policy (2000) 
Maryam Jamilah | Motif Kerjasama Antara KRG (Kurdish Regional Government) Irak Dengan Pemerintah Turki (2013-2016)

Robert Elliot, Ladislav Timulak, Descriptive and Interpretive approaches to Qualitative Research (2000)

Ronald D. Crelinsten, Terrorism and Counter Terrorism in a Multi-Centric World: Challenges and Opportunities, Terrorism and Political Violence 11, no 4 , (1999), 172

Stephen F. Larrabee, Turkey Rediscovers the Middle East, Foreign Affairs, Vo.86, No. 4 (Juli-Agust 2007), 104

Shwan Zulal, The real deal behind Turkish-Kurdish oil Plans: pipe dreams or reality?,(22 Juni 2012),http://www.ekurd.net/mismas/articles/misc2012/6/state6311.htm,, (tanggal akses: 20 Desember 2016)

Soner Cagaptay \& Tyler Evans, Turkey's Changing Relations with Iraq, Policy Focus 122, (Oktober 2012), 1

Sozen,Ahmet, A Paradigm Shift in Turkish Foreign Policy: Transition and Challenge, Turkish Studies (Routledge) XI, no. 1 (Maret 2010), 103-123

Till F. Paasche \& Howri Mansurbeg, Kurdistan Regional Government-Turkish energy relations: a complex partnership, Eurasian Geography and Economics,(2014), diakses dari http://www.tandfonline.com/page/terms-and-conditions

Tol,Gonul, 2015,Forum 2015 Session 6: Turkey-KRG Relations: Sharing Visions for the future, Middle East Research Institute,http://www.meri-k-org/multimedia/forum-2015session-6-turkey-krg-relations-sharing-visions-for-the-future/ , 2013 (tanggal akses: 08 Desember 2016)

Turkish Ministry of Foreign Affairs, Statement Made by Ismail Cem, Foreign Minister on the Special Security Meeting Held between Turkey and Syria 20 Oktober 1998 (Unofficial Translation)http://www.mfa.gov.tr/_p_statement-made-by-ismail-cem_-foreignminister_on-the-special-security-meeting-held-between-turkey-and-syria_br_october20_1998 br unofficial-translation p p.en.mfa, (tanggal akses: 17 Desember 2016)

Turkey Probes Possible Iran Link in Bombing Near Syria, Haaretz, 23 Agustus 2012, http://www.haaretz.com/news/middle-east/turkey-probes-possible-iran-link-inbombing-near-syria-1.460372, (tanggal akses: 20 Desember 2016)

Turunc,Hasan, Turkey and Iraq, Turkey's Global Strategy Special Report 7, (2011)

Uras,Umut, Kurdish Leader Makes Historic Turkey Visit, www.aljazeera.com (tanggal akses: 20 November)

Vickie A. Lambert, Clinton E. Lambert, Qualitative Descriptive Research : An Acceptable Design, (2000)

\section{BIOGRAPHY}

Maryam Jamilah, mendapatkan gelar Sarjana Ilmu Politik pada tahun 2015 dari Jurusan Ilmu Hubungan Internasional Universitas Andalas. Pada tahun 2017 dia berhasil menyelesaikan program magister dan mendapatkan gelar Magister Scienece (M.Si) dari Program Kajian Timur Tengah dan Islam, Sekolah Kajian Stratejik dan Global Universitas Indonesia. Adapun judul tesisnya adalah "Partisipasi Perempuan Israel dalam Proses Perdamaian Israel-Palestina". Artikel dari tesis tersebut telah dipublikasikan dalam proceeding Asia Pacific Reseach Forum for Research in Social Science and Humanities (APRISH) 2017. Adapun research interest nya yaitu: Kajian Timur Tengah, Ekonomi Politik Internasional dan Feminisme serta Kajian Islam dalam Hubungan Internasional. 